\title{
II Quadriportico della Cattedrale di S. Matteo: sensori low cost per rilievi di rapid mapping
}

\author{
Marika Falcone \\ Massimiliano Campi
}

Abstract

Con il progresso tecnologico anche gli smartphone hanno sviluppato fotocamere integrate, sempre più performanti, e sensori in grado di monitorare lo stato di salute del corpo umano (battito, consumo di calorie, ect.) e di acquisire informazioni metriche e colorimetriche. La loro attitudine a trasmettere dati in tempo reale li ha resi di grande interesse, soprattutto, nel campo architettonico. Pertanto, con lo scopo di indagare e sviluppare metodologie di rapid mapping ai fini del monitoraggio continuo, è stato testato il nuovo sensore LiDAR, recentemente implementato su devices portatili come I'Iphone I2 PRO. La finalità dell'operazione è stata quella di effettuare scansioni digitali rapide, elaborate da smartphone, che poi sono state comparate con la nuvola di punti ottenuta da un rilievo fotogrammetrico di tipo terrestre. Sulla base dei risultati ottenuti è stato possibile valutare limiti e potenzialità di queste due tecniche di acquisizione low cost. Come caso studio è stato analizzato il lato del nartece del Quadriportico della Cattedrale di San Matteo a Salerno, testimonianza storico-architettonica del periodo normanno.

Quadriportico, strumentazioni low cost, rilievo fotogrammetrico, scansione LiDAR da smartphone, comparazione.

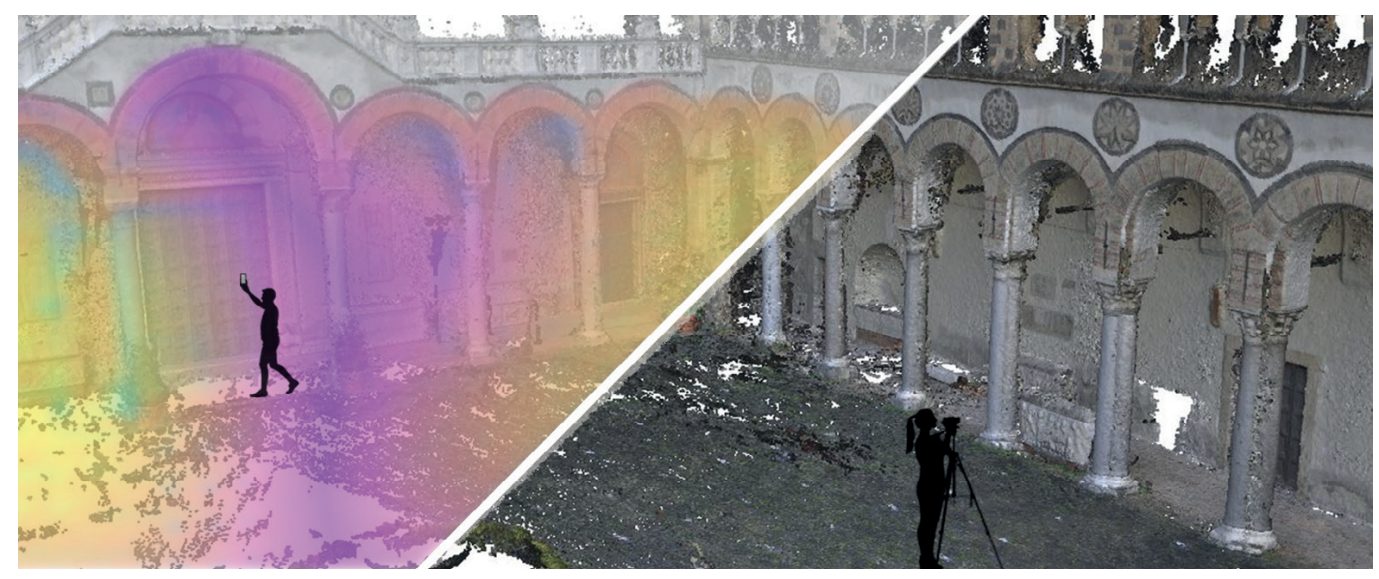




\section{Introduzione}

Negli ultimi decenni, il campo dei beni culturali è stato uno dei terreni di sperimentazione più interessanti per lo sviluppo di nuove metodologie di rilevamento. Ai fini della documentazione, conservazione e valorizzazione del Patrimonio Culturale, tali metodologie consentono di generare modelli digitali tridimensionali sempre più accurati, mediante l'utilizzo di flussi di lavoro basati sia su sensori image based che su sensori range based [Di Luggo 20 19, pp. I I 5- I22; Repola 20 19, pp. 96 I-968; Barni 2020, pp. I678- I 699]. L'evoluzione digitale ha cambiato, dunque, totalmente le modalità di acquisizione e gestione dei dati con l'implementazione di sensori che hanno offerto soluzioni soddisfacenti sia dal punto di vista tecnico che tecnologico, riducendo in maniera evidente i tempi di lavoro e i costi delle strumentazioni. Recentemente, l'industria dell'loT (Internet of Things) ha aperto la strada a nuove sperimentazioni che vanno ben oltre le tradizionali e oramai note applicazioni 'sensoristiche'. Partendo da tali premesse, la comunità scientifica, ha focalizzato l'attenzione anche sull'utilizzo di sensori low cost finalizzati, in particolar modo, alle fasi di diagnostica e monitoraggio delle architetture che richiedono registrazioni di tipo continuo con tecniche di rilievo speditivo [Calantropio 20 I 8, pp. 31-45; Russo 20 I9, pp. 287-294]. Tra le tecniche di rilevamento, considerate a basso costo, la fotogrammetria digitale, di tipo aerea e/o terrestre, è sicuramente la metodologia preferita e consolidata. Con il progresso tecnologico, anche gli smartphone e i tablet hanno sviluppato, in modo repentino, fotocamere integrate sempre più performanti e sensori non solo in grado di monitorare alcuni parametri del corpo umano quali ad esempio il battito cardiaco e il consumo calorico, ma, anche, di acquisire dati metrici e colorimetrici sempre più accurati. La loro attitudine a trasmettere dati in tempo reale li ha resi di grande interesse, soprattutto, nel settore architettonico speditivo. In tale contesto, si inserisce il presente contributo, parte di una ricerca più ampia e tutt'ora in corso, condotta come sperimentazione nell'ambito del dottorato di ricerca in Architettura presso l'Università degli Studi di Napoli Federico II. Con lo scopo, quindi, di esplorare nuove metodologie di rapid mapping è stato testato, in ambito architettonico il sensore LiDAR (Light Detecting And Ranging), recentemente integrato su mobile devices quali l'IPad Pro e l'Iphone I2 Pro della Apple. Le scansioni digitali, elaborate dallo smartphone, sono state in seguito comparate con l'output prodotto dal rilievo fotogrammetrico di tipo terrestre, elaborato sullo stesso oggetto architettonico. Sulla base dei risultati ottenuti è stato possibile valutare le potenzialità di queste tecniche di acquisizione low cost al fine di ipotizzare nuove soluzioni e strategie per la diagnostica e il monitoraggio continuo, funzionali anche ad analisi predittive del patrimonio architettonico. Lo studio è stato condotto sul lato del nartece del Quadriportico della Cattedrale di San Matteo, testimonianza storico-architettonica del periodo normanno nella città di Salerno (fig. I).

\section{Caso Studio}

Dopo un assedio durato sette mesi, nel dicembre del 1076, le armate normanne guidate da Roberto il Guiscardo conquistarono la città di Salerno ponendo fine al dominio longobardo [Braca 2018, pp. 19-44]. Con la conquista dell'Opulenta Salernum, che in quegli anni conobbe il suo massimo splendore, fu edificata la cattedrale dedicata all'evangelista Matteo. L'imponente fabbrica, finanziata dal Guiscardo e progettata dal vescovo Alfano I, appartenente all'ordine benedettino, fu realizzata esemplando il modello dell'Abbazia di Montecassino. Essa era visibile da qualsiasi punto della città sorgendo nello stesso luogo ove erano ubicate la basilica di Santa Maria degli Angeli e l'annessa chiesa di San Giovanni Battista, entrambe demolite per lasciar posto alla maestosa cattedrale. L'inizio dei lavori avvenne nel I08I, in seguito al ritrovamento delle spolie del Santo e dopo pochi mesi fu inaugurata la Cripta che costituì il primo nucleo nella costruzione del Duomo. Poco dopo seguì la costruzione della basilica superiore procedendo, come era usanza nei cantieri medievali, dal transetto fino al Quadriportico sul cui lato meridionale fu innalzato il monumentale 
Fig. I || Quadriportico della Cattedrale di San Matteo a Salerno. In alto: lato est detto anche "lato del nartece": Da sinistra: lato sud, lato ovest e lato nord.

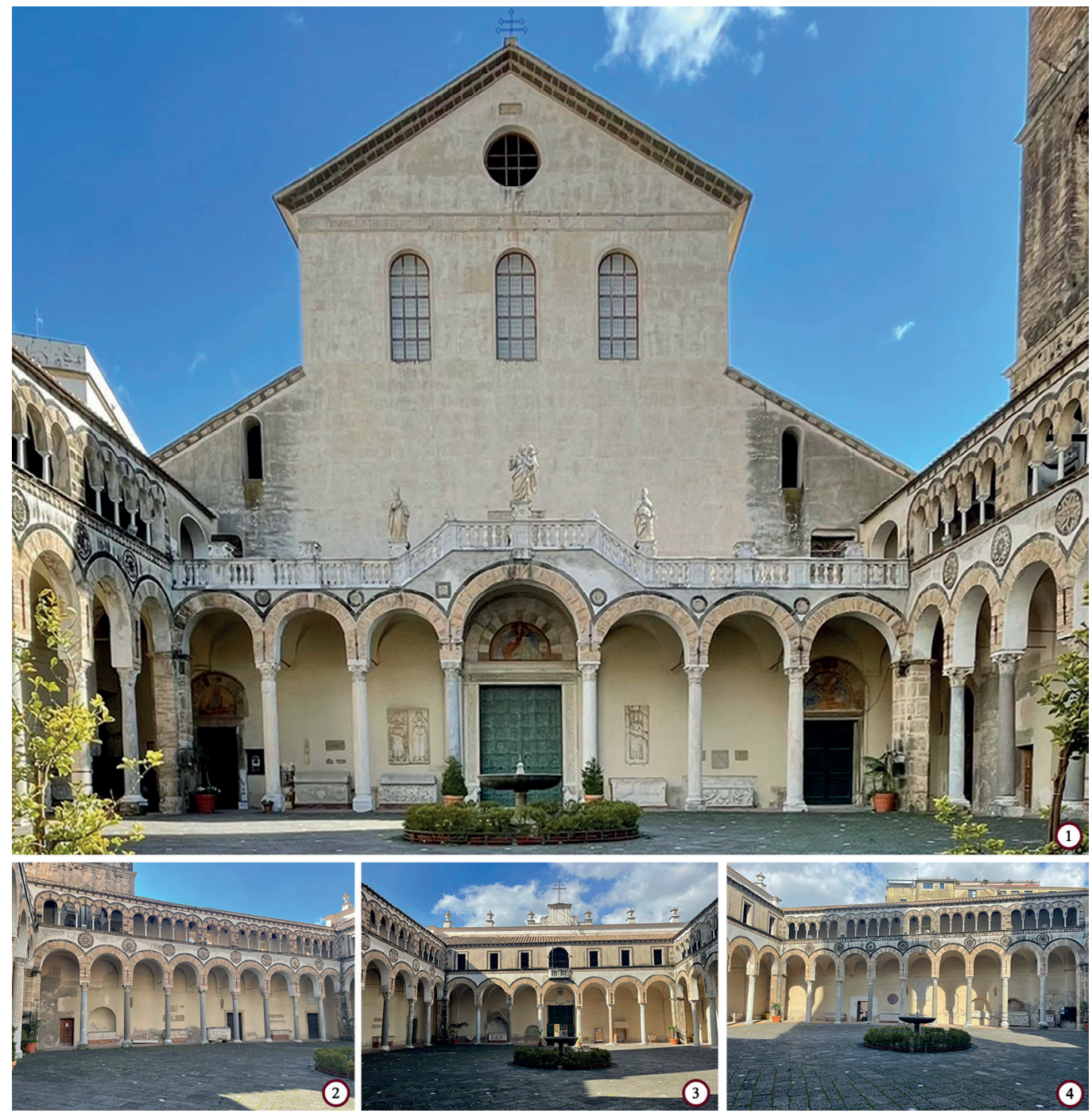

campanile normanno, realizzato su committenza dell'arcivescovo Guglielmo da Ravenna [Memoli 2009, pp. 183-185].

Durante il periodo barocco si erano perse completamente le tracce del Quadriportico di età medievale. Solo in seguito ai lavori di restauro del secondo dopoguerra, sono stati rinvenuti notevoli resti dell'assetto originario dell'atrio, completamente nascosti da intonaci, pennacchi e tamponature del periodo settecentesco. Oggi, l'atrio, meglio noto come Quadriportico, di forma pressoché quadrata, è costituito da un porticato sorretto da quattro pilastri angolari e da ventotto colonne di spoglio [I], la maggior parte provenienti dall'area del foro di Paestum, sui cui piedritti si innalzano archi a tutto sesto rialzato. Lungo il portico si possono ammirare diversi sarcofagi di fattura romana [2] [Di Domenico 2020, pp. I35-145] mentre le facciate degli archi sono decorate con tarsie e rosoni ornamentali che, insieme ai differenti materiali lapidei, conferiscono un aspetto scenico sorprendente. II loggiato, invece, posizionato al di sopra dei bracci laterali, è caratterizzato da due coppie di pentafore disposte simmetricamente ai lati della bifora centrale. Sul lato del nartece, ossia il lato addossato alla facciata principale, si erge la 'porta di bronzo' di epoca normanna, inscritta in un portale marmoreo. Essa è costituita da 54 formelle metalliche raffiguranti, in gran parte, croci bizantine. Nella parte superiore, sulla balaustra in marmo, campeggiano le statue dei santi Matteo, Bonosio e Grammario [Braca 2003, pp. 5 I-77]. 


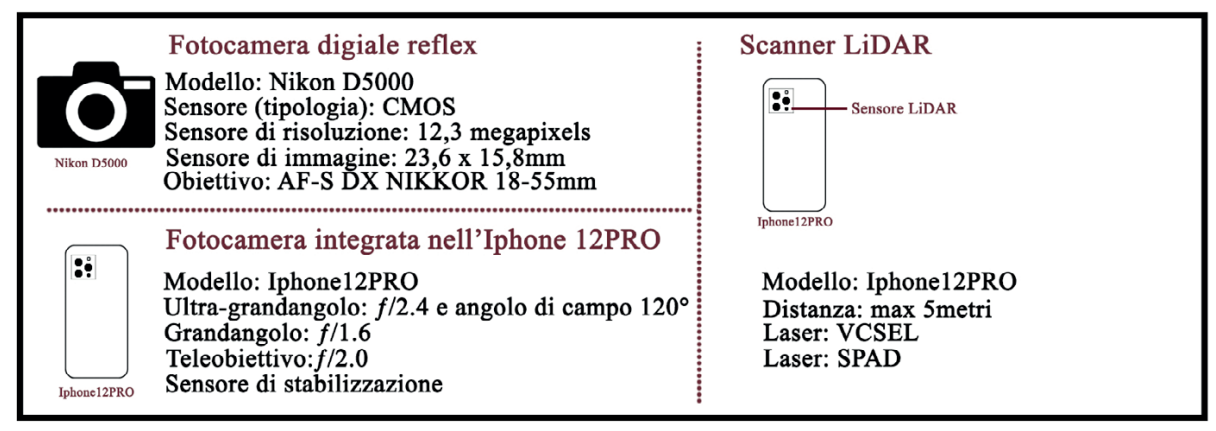

\section{I sensori low cost utilizzati}

Prima di procedere alle fasi di acquisizione dei dati in situ è stato opportuno valutare, innanzitutto, le caratteristiche sia tecniche che tecnologiche dei sensori utilizzati ai fini della ricerca. Pertanto, il rilievo condotto sul caso studio ha visto l'impiego di due specifiche metodologie image based e range based con strumentazioni però di tipo low cost, owero una fotocamera digitale Nikon D5000 e uno smartphone Iphone I2PRO (fig. 2). Per la tecnica image based il dataset fotografico è stato registrato con fotocamera digitale Nikon D5000 con sensore CMOS, con dimensione delle immagini di 23,6 X I5,8 mm, risoluzione I2,3 megapixels ed obiettivo AF-S DX NIKKOR I8-55mm. Per aumentare la stabilità delle immagini è stato utilizzato in fase di ripresa anche un cavalletto fotografico. Invece, per la tecnica range based, nell'ambito di questa ricerca, ci si è awalsi del sensore LiDAR, implementato su smartphone. Nell'ultima versione PRO del modello di casa Apple, è stato, difatti, integrato questo sensore a stato solido che si compone di due elementi principali: un trasmettitore ed un ricevitore, rilevando distanze massime fino a 5 metri sia in ambienti outdoor che indoor. II sensore che trasmette è un array VCSEL (vertical cavity surface emitting lasers) mentre il sensore che riceve è di tipo SPAD (single photon avalanche diodes). Combinando le informazioni in real time è possibile leggere, tramite app, la scansione ottenuta discretizzata sottoforma di maglia triangolare. Al contempo, importanti cambiamenti sono stati apportati anche al sistema fotografico posteriore [3], dello stesso smartphone, in particolar modo all'obiettivo quadrangolare, dotato di una lente a sette elementi con apertura f/l.6 e all'obiettivo ultra-grandangolare con apertura f/2.4.

\section{Le acquisizioni fotogrammetriche}

Inizialmente, per la prima fase dell'indagine è stato effettuato un rilievo fotogrammetrico terrestre dell'intero Quadriportico utilizzando una fotocamera digitale Nikon D5000. La presenza dell'ambiente porticato ha, però, richiesto un'importante fase di pianificazione della battuta fotografica, al fine di evitare punti ciechi e zone d'ombra. Per questo motivo il dataset fotografico è stato suddiviso in relazione agli elementi: prospetti, sottoportico e colonne interne ed esterne; in totale, sono stati acquisiti 602 fotogrammi, in cui è stato garantito un overlap delle immagini di circa il $60 \%$ e, in relazione alla conformazione degli spazi, si è deciso di settare la lunghezza focale a $24 \mathrm{~mm}$ integrando riprese sia ad assi paralleli che ad assi convergenti. In tal modo sono state recuperate informazioni spaziali su differenti livelli di profondità limitando, al contempo, gli errori di distorsione. Per il rilievo delle colonne [4] è stato, invece, necessario scattare 5 immagini percorrendo, per ogni colonna, un semicerchio (fig. 3). Successivamente, il 'processamento' delle immagini è stato effettuato con l'applicativo structure from motion dell'Agisoft - Metashape ove in tutte le fasi di lavori sono stati impostati parametri di media qualità (fig. 4). In linea con il workflow fotogrammetrico, dopo le fasi di allineamento è stata estratta la nuvola sparsa di 178,898 punti. Con il riconoscimento dei punti omologhi è stato possibile ottenere, con algoritmi di dense image matching, il modello poligonale texturizzato, costituito da una maglia triangolare di 7,959,089 facce [Remondino 20 17, pp.59I-599]. Infine, dal modello texturizzato è stata elaborata l'ortofoto impiegata per l'elaborazione grafica del lato del nartece (fig.5). 
Fig. 3 Rilievo fotogrammetrico: schema dell'acquisizione dei dati in situ.
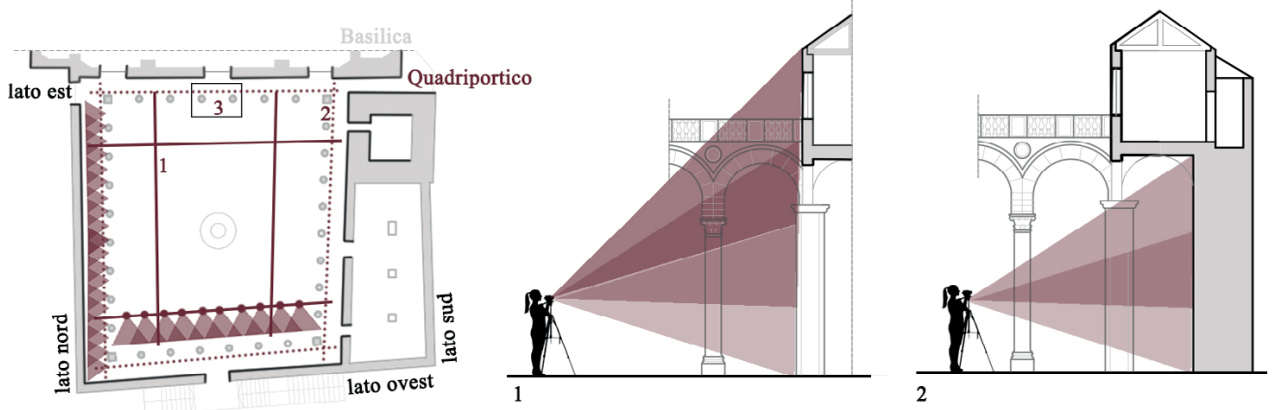

Rilievo fotogrammetrico del Quadriportico Schema della battuta fotografica

- 1_Facciate del Quadriportico

...... 2_Parti del sottoportico

- 3.Dettaglio colonna

Numero di fotogrammi acquisiti: 602

Tecnica di ripresa: Foto ad assi paralleli

Tempo di acquisizione: 1 giorno

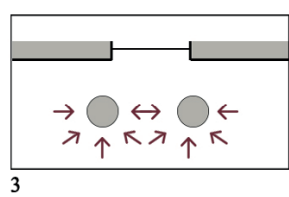

\section{Le acquisizioni da LiDAR scanner su smartphone}

In seguito alla valutazione delle caratteristiche tecnologiche della strumentazione presa in esame, per l'acquisizione delle scansioni da smartphone, il rilievo è stato condotto esclusivamente sul lato del nartece del Quadriportico e poi, per un maggiore dettaglio, sugli elementi architettonici della porta medievale e del sarcofago di Guglielmo d'Altavilla, presenti sempre su questo lato del Quadriportico. In realtà, durante la fase di registrazione dei dati Lidar scanner, in prossimità della porta d'ingresso della Chiesa, vi è erano diversi oggetti, che impedivano il passaggio

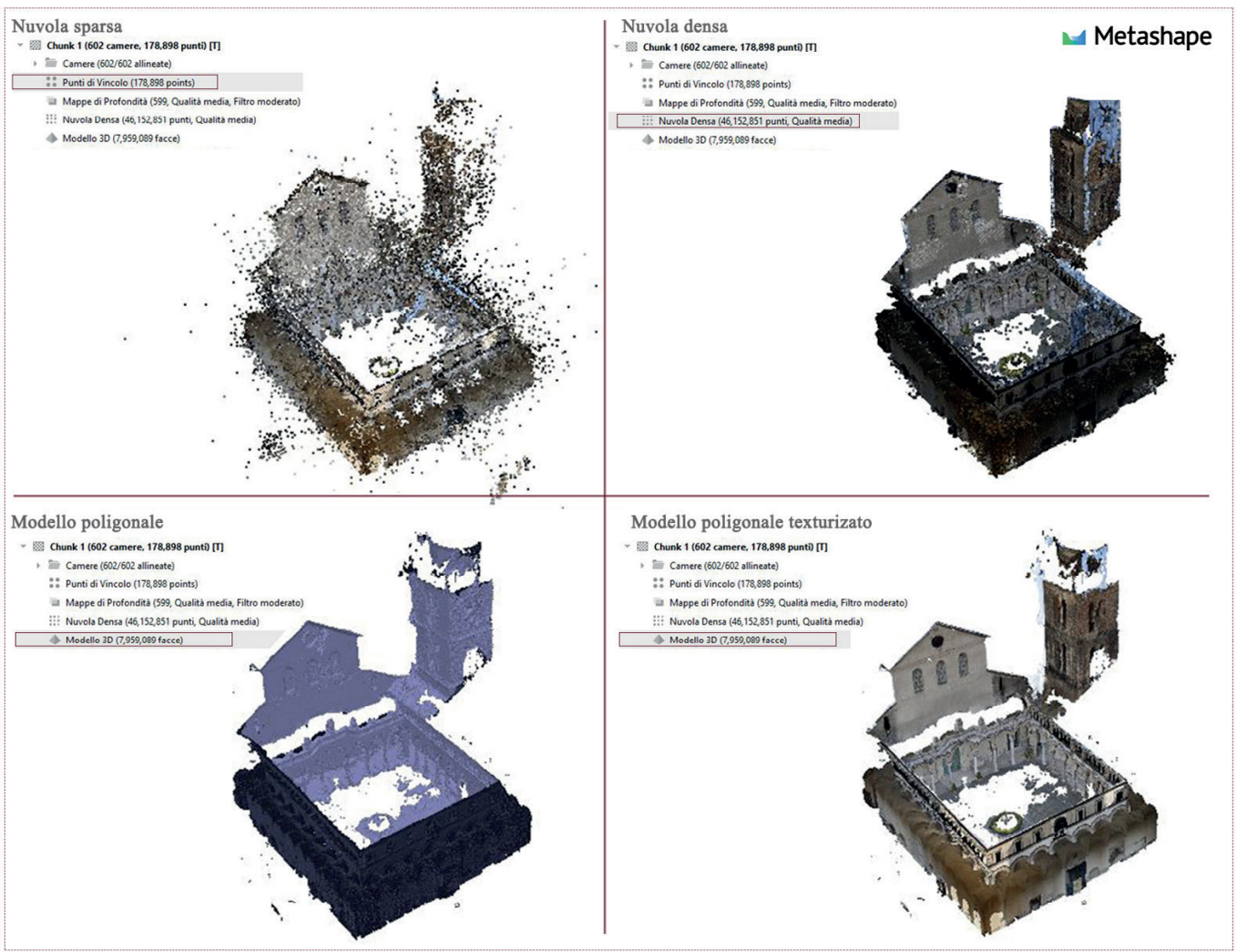




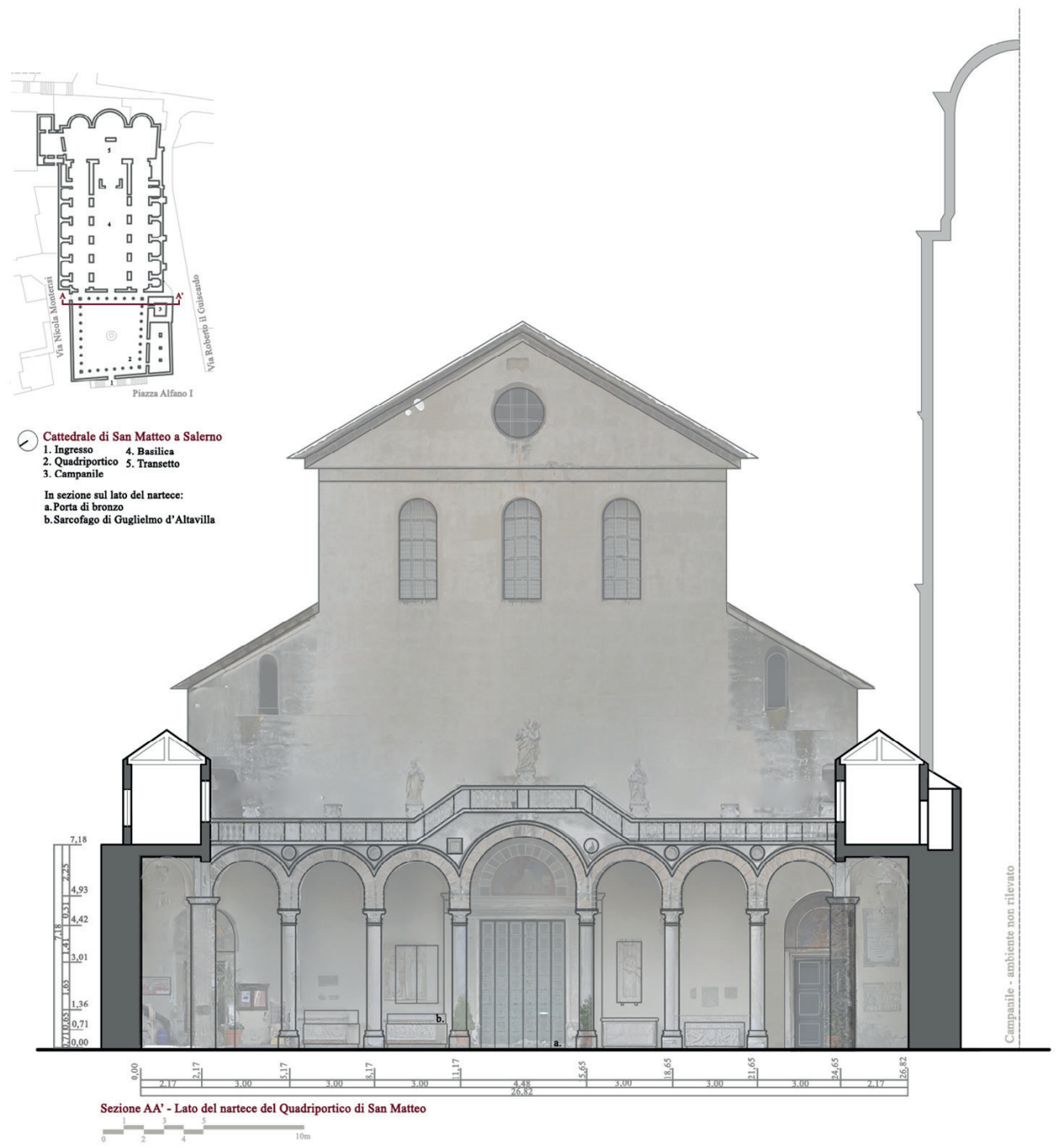

creando problemi durante la fase di ripresa. Pertanto, ai fini della comparazione, questo lato non è stato oggetto di valutazione. L'obiettivo principale è stato quello di individuare potenzialità e limiti di questo sensore per cui, le diverse scansioni sono state registrate con parametri di risoluzione sia high res che low res, settando di volta in volta i valori tramite l'app utilizzata, ossia 3DScanner. Camminando con passo moderato e tenendo in mano lo smartphone, con il sensore rivolto verso l'architettura, sono state raccolte le informazioni spaziali. In prossimità del colonnato è stato opportuno ruotare intorno ad ogni colonna cercando di inquadrare con più precisione le parti del basamento e del capitello mentre, il soffitto voltato del portico non è stato rilevato dal sensore poiché posto a quota superiore di 5 metri. Per ovviare a questo problema ed acquisire anche la lunetta con arco a tutto sesto posta al di sopra della porta di bronzo, lo smartphone è stato montato su asta telescopica. In 8 minuti è stata portata a termine la registrazione del lato del nartece. Per il monumento funebre e la porta medievale sono state effettuate, in circa 6 minuti, altre due scansioni (fig. 6). Successivamente, sempre attraverso l'app, si è proceduti all'elaborazione delle texture e, in tal caso, i parametri sono stati nuovamente regolati in funzione delle dimensioni dell'oggetto acquisito. Ė necessario precisare che tale processo ha occupato uno spazio su storage di $3 G B$ e un tempo di elaborazione di circa 22 minuti per la scansione dell'intero ambiente mentre l'elaborazione delle texture sulle parti di dettaglio hanno impiegato 5 minuti. Queste ultime due fasi hanno ridotto notevolmente la percentuale di batteria per l'alto carico computazionale. Infine, le scansioni sono state esportate nei differenti formati disponibili presenti nell'applicazione (fig. 7). 
Fig. 6 Rilievo LiDAR da smartphone: schema dell'acquisizione dei dati in situ.
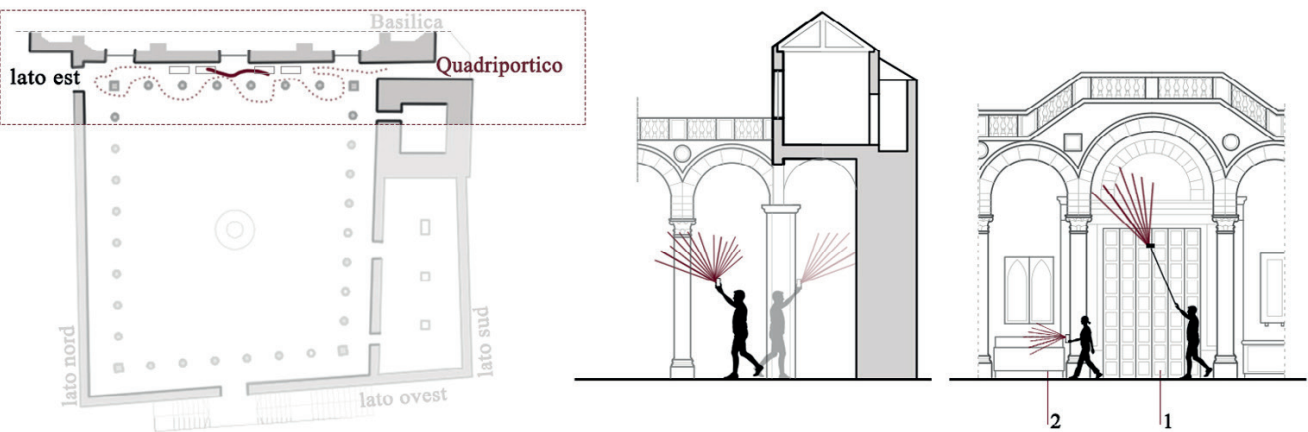

Rilievo LiDAR da Iphone12PRO

Schema della ripresa delle scansioni

....... Scansioni effettuate sul lato est detto del "lato del nartece"

- Scansioni effettuate sulla porta di bronzo (1) e sul sarcofago (2)

Tempo di acquisizione: 8 minuti per il lato est

6 minuti per la porta di bronzo e il sarcofago

\section{Comparazione dei dati}

Sulla base dei risultati ottenuti è stato possibile effettuare un primo confronto tra le due metodologie low cost prese in esame. Allo scopo di valutare l'accuratezza dei due sistemi è importante tenere in considerazione anche la modalità in cui i dati sono stati acquisiti. Difatti, mentre per la prima metodologia si è seguito una tecnica di ripresa precisa, per il dispositivo mobile i dati sono stati registrati in movimento spostandosi liberamente da una parte all'altra. II primo confronto, ha visto come oggetto di analisi il lato del nartece, e la comparazione delle points clouds è avvenuta all'interno del software open source Cloud
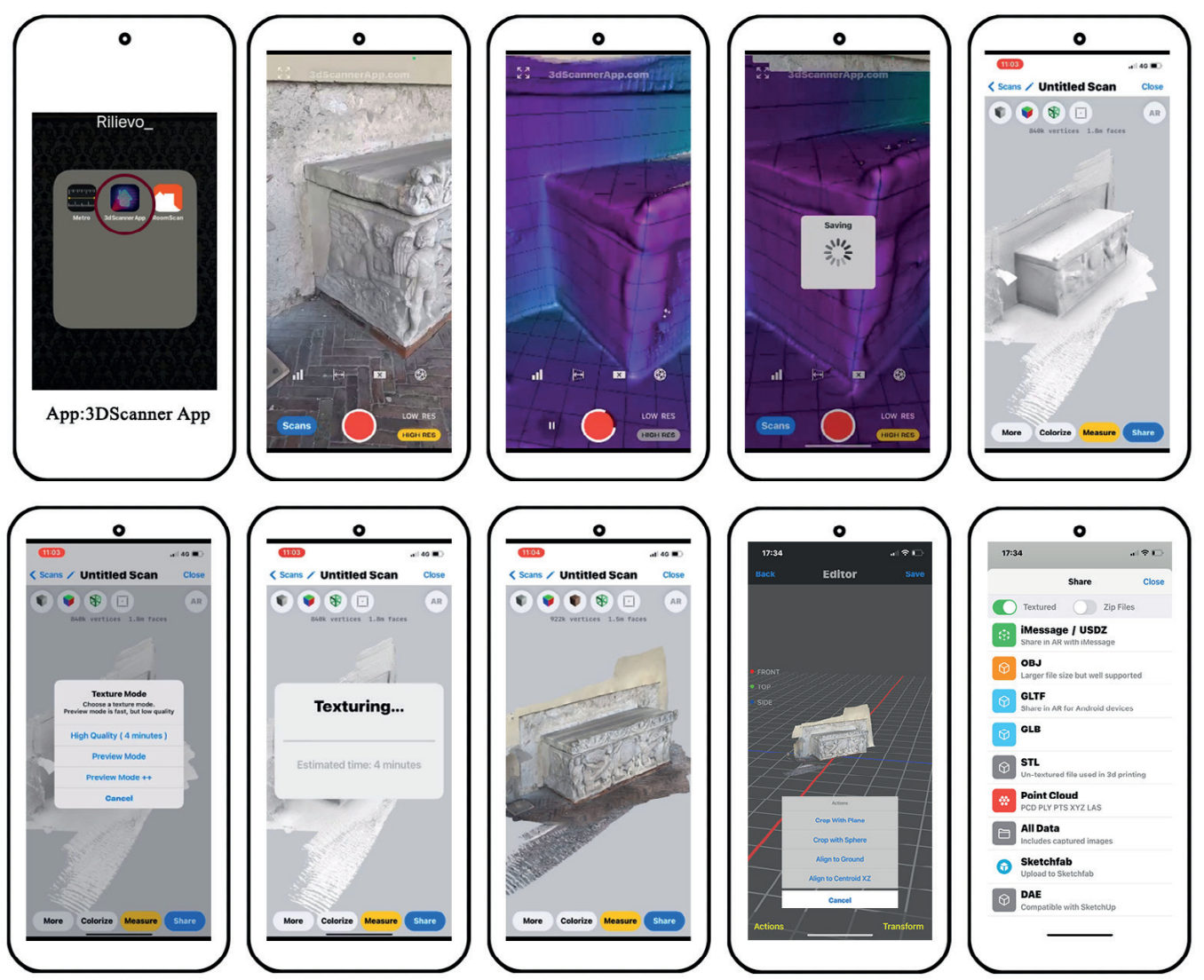

Fig. 7 Rilievo Lidar da processamento ed elaborazioni dei dati mediante app 3Dscanner. d'Altavilla. 
Compare, integrando in un unico modello l'output del rilievo fotogrammetrico con la nuvola di punti prodotta dalla scansione LiDAR. II dataset fotogrammetrico è stato scelto come 'reference' per la procedura di registrazione con l'algoritmo ICP (Iterative Closest Point) e, a partire dalla collimazione dei punti omologhi visibili in ciascuna scansione nelle aree di sovrapposizione tra due, sono stati calcolati successivamente i valori di distanza. II risultato del calcolo cloud2cloud ha mostrato, nella parte evidenziata oggetto di analisi, un'ampia area di sovrapposizione tra i datasets con un errore medio di $0.15 \mathrm{~m}$. Parallelamente, con la stessa procedura, sono stati confrontati gli elementi di dettaglio sia della porta di bronzo che del sarcofago. In tal caso l'allineamento finale delle nuvole di punti ha portato a risultati molto più soddisfacenti in termini di accuratezza del dato metrico con un valore distanza max contenuto nei $2 \mathrm{~cm}$ nonostante i ridotti tempi della fase di acquisizione (fig. 8).

Fig. 8 Allineamento e calcolo della deviazione tra le due nuvole di punti (rilievo fotogrammetrico e rilievo lidar) in CloudCompare - Porta di Bronzo e lato del nartece.
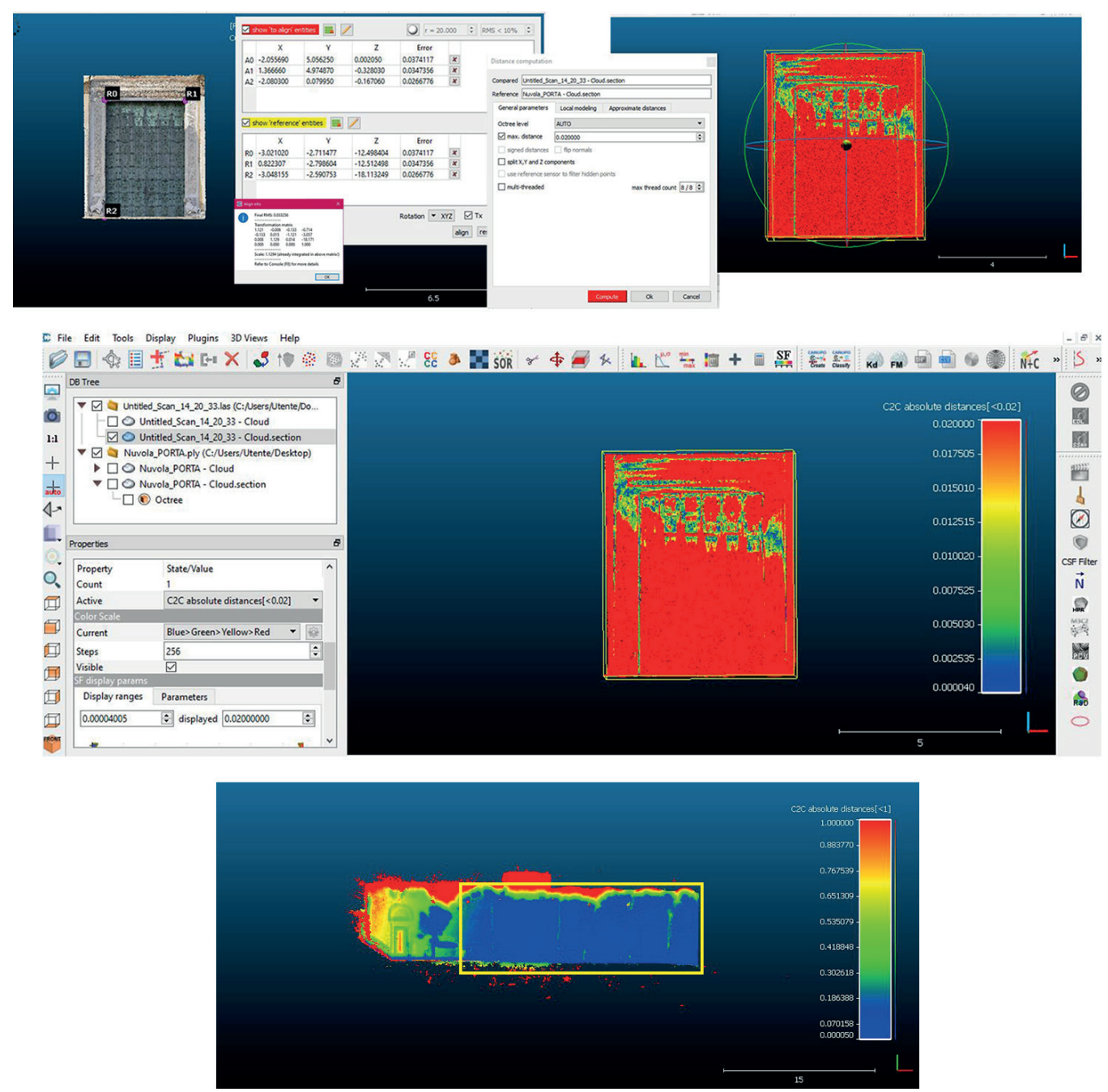

\section{Conclusioni}

Tenendo conto che ad oggi la tecnologia LiDAR implementata su smartphone è realizzata principalmente per applicazioni di realtà aumentata e non ancora con finalità di tipo conoscitivo-architettonico, i risultati ottenuti da questa prima sperimentazione sono nel complesso piuttosto soddisfacenti, soprattutto considerando le dimensioni ridotte del sensore e la portabilità del dispositivo. Sicuramente è necessario valutare che l'accuratezza del dato Lidar non è ancora ottimale per gli ambienti di notevoli dimensioni così come nel caso del 
lato del nartece, mentre può ritenersi soddisfacente per gli oggetti di dimensioni ridotte. Le tecniche esaminate potrebbero essere integrate l'una con l'altra ma, naturalmente, occorre tener sempre presente la finalità del rilievo da dover effettuare. Ad esempio, per le fasi di diagnostica e monitoraggio, ove è richiesta una tecnica di rapid mappig continua, la metodologia LiDAR con sensori come quelli usati in questa applicazione può fungere solo da supporto a tecniche consolidate, come ad esempio la fotogrammetria digitale. Allo stesso tempo, però, possiamo supporre che rapidi sviluppi tecnologici ulteriori, riguardanti la miniaturizzazione e la migliore performance in termini di accuratezza, consentiranno molto presto nuovi e interessanti scenari applicativi con strumenti portatili efficaci per il rilievo.

\section{Note}

[I] Sei colonne sono disposte sui due lati di prospetto mentre otto sono disposte lungo i laterali.

[2] I sarcofagi romani, all'interno del Quadriportico, sono disposti in modo casuale senza seguire un ordine cronologico ben preciso.

[3] In questo caso è stata adottata la stabilizzazione ottica su sensore, tecnologia riservata alle fotocamere reflex digitali.

[4] Ogni fotogramma è stato acquisito percorrendo un semicerchio a $0^{\circ}, 45^{\circ}, 90^{\circ}, 135^{\circ}$ e $180^{\circ}$.

\section{Riferimenti bibliografici}

Barni R., Bianchini C., Inglese C. (2020). II duomo di Orvieto. Rilievo integrato e modellazione/The Cathedral of Orvieto. . In Arena A., Arena M., Brandolino R.G., Colistra D., Ginex G., Mediati D., Nucifora S., Raffa P. (a cura di). Connettere. Un disegno per annodare e tessere. Atti del $42^{\circ}$ Convegno Internazionale dei Docenti delle Discipline della Rappresentazione/Connecting. Drawing for weaving relationships. Proceedings of the 42th International Conference of Representation Disciplines Teachers, pp. $1678-1699$. Milano: FrancoAngeli.

Braca A. (2003). Il Duomo di Salerno. Architettura e culture artistiche del Medioevo e dell'età moderna. Salerno: Laveglia editore, pp. 5 I-77.

Braca A. (20 I 8). Guida illustrata alla Cattedrale di San Matteo. Salerno: Opera edizioni.

Calantropio A. et al. (20/8). Low-cost sensors for rapid mapping of cultural heritage: first tests using a COTS Steadicamera. In Appl Geomat, n. 10, pp. 3 I-45.

Di Domenico G., Galante M., Pontrandolfo A. (a cura di). (2020). Opulenta Salernum. Una città tra mito e storia. Roma: Gangemi Editore.

Di Luggo A. et al. (2019). Evaluation of historical heritage documentation: reality-based survey and derivative models. In International Archives of the Photogrammetry, Remote Sensing and Spatial Information Sciences, n. XLII-M I 7, pp. I I 5- I 22.

Memoli Apicella D. (2009). Sichelgaita tra longobardi e normanni. Salerno: Laveglia Carlone.

Remondino F. et al. (2017). A critical review of auto-mated photogrammetry processing of large dataset. In International Archives of the Photogrammetry, Remote Sensing and Spatial Information Sciences, n. XLII-2NW5, pp.59I-599.

Repola L. et al. (2019). La rappresentazione quale specchio del reale: le nuove tecnologie a servizio della conoscenza per la documentazione di ambienti complessi. In Belardi P. (a cura di). Riflessioni l'arte del disegno/ il disegno dell'arte. Atti del $4 l^{\circ}$ Convegno internazionale dei docenti della Rappresentazione. Perugia, 19-2 I settembre 20 19, pp. 96 I-968. Roma: Gangemi Editore.

Russo M., Giugliano A.M., Asciutti M. (2019). Mobile phone imaging for $\mathrm{CH}$ façade modelling. In International Archives of the Photogrammetry, Remote Sensing and Spatial Information Sciences, n. XLII-MI 7, pp. 287-294.

Autori

Marika Falcone, Università degli studi di Napoli “Federico II”, marika.falcone@unina.it

Massimiliano Campi, Università degli studi di Napoli “Federico II", campi@unina.it

Per citare questo capitolo: Falcone Marika, Cami Massimiliano (202I). Il Quadriportico della Cattedrale di S. Matteo: sensori low cost per rilievi di rapid mapping/The Quadriportico of the Cathedral of S. Matteo: Low-cost Sensors for Rapid Mapping Surveys. In Arena A. Arena M. Mediati D. Raffa P. (a cura di). Connettere. Un disegno per annodare e tessere. Lingugogi Distanze Tecnologie. Atti del $42^{\circ}$ Convegno Internazionale dei Docenti delle Discipline della Ropresentazine/Connecting Drawing for Conference of Representation Disciplines Teachers. Milano: FrancoAngeli, pp. 2283-2300. 


\title{
The Quadriportico of the Cathedral of S. Matteo: Low-Cost Sensors for Rapid Mapping Surveys
}

\author{
Marika Falcone \\ Massimiliano Campi
}

\section{Abstract}

With technological progress, smartphones have also developed integrated cameras, increasingly performing, and sensors capable of monitoring the health of the human body (heart rate, calorie consumption, etc.) and acquiring metric and colorimetric information. Their ability to transmit data in real time has made them of great interest, especially in the field of architecture. Therefore, with the aim of investigating and developing rapid mapping methodologies for continuous monitoring, the new LiDAR sensor, recently implemented on portable devices such as the Iphone 12 PRO, was tested. The purpose of the operation was to perform rapid digital scans, processed by smartphones, which were then compared with the point cloud obtained from a terrestrial photogrammetric survey. Based on the result obtained, it was possible to evaluate the limits and potential of these two low-cost acquisition techniques. As a case study, the east side of the Quadriportico of the Cathedral of San Matteo in Salerno, a historical-architectural testimony of the Norman period, was analysed

\section{Keywords}

Quadriportico, low-cost sensors, photogrammetric survey, Lidar scan from smartphone, comparison.

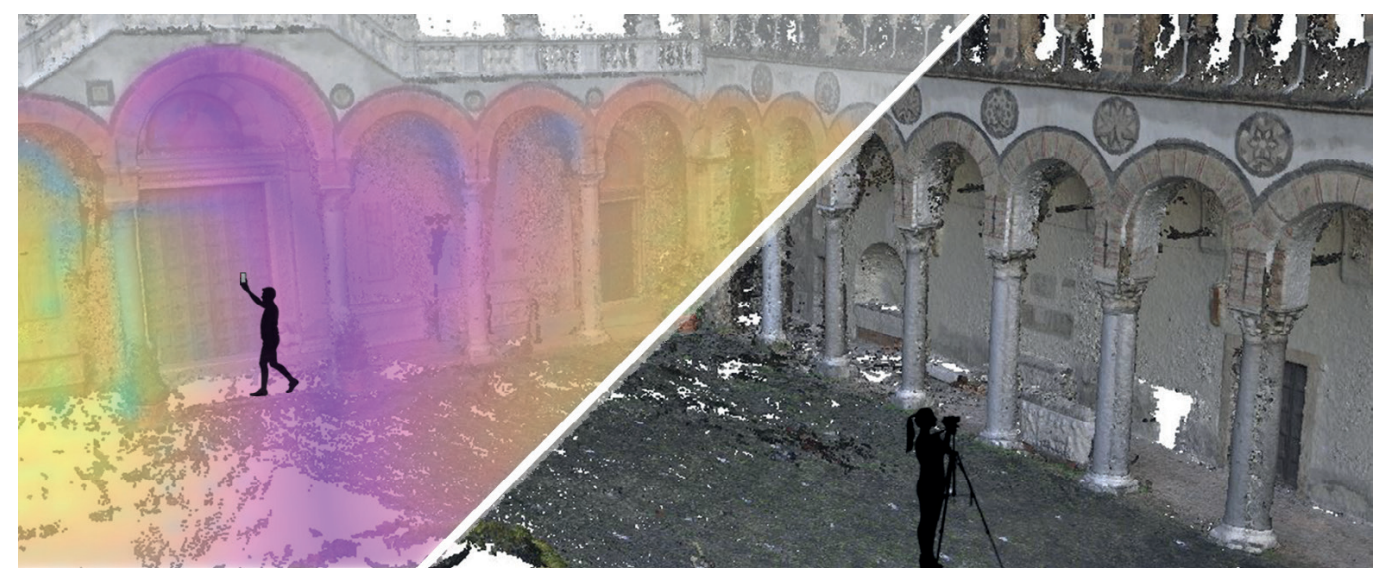




\section{Introduction}

In recent decades, the digitization of cultural heritage has been one of the most interesting experimentation fields for the development of new survey methodologies. For the purposes of documentation, conservation and enhancement of Cultural Heritage, these methodologies make it possible to generate increasingly accurate three-dimensional digital models, with image-based and range-based sensors [Di Luggo 2019, pp. I I 5- 122; Repola 2019, pp. 96I-968; Barni 2020, pp. 1678-1699]. The digital evolution has therefore totally changed the methods of data acquisition and management with the implementation of sensors that have offered satisfactory solutions both from a technical and technological point of view, clearly reducing work times and instrumentation costs. Recently, the loT (Internet of Things) industry has led to new experiments that go far beyond the traditional and now well-known sensor applications. Starting from these premises, the scientific community has also focused attention on the use of low-cost sensors aimed, in particular, at the diagnostic and monitoring phases of the architectures that require continuous recordings with rapid survey techniques [Calantropio 2018, pp. 31-45; Russo 2019, pp. 287-294]. Among the detection techniques, considered low cost, digital photogrammetry, of the aerial and / or terrestrial type, is certainly the preferred and consolidated methodology. With technological progress, even smartphones and tablets have suddenly developed increasingly high-performance integrated cameras and sensors not only able to monitor some parameters of the human body such as heart rate and calorie consumption, but also to acquire ever more accurate metric and colorimetric data. Their aptitude for transmitting data in real time has made them of great interest, especially in the expeditious architectural sector. In this context, this contribution is part of a broader and still ongoing research conducted as an experiment in the context of the PhD in Architecture at the Federico II University of Naples. With the aim, therefore, of exploring new rapid mapping methodologies, the LiDAR sensor (Light Detecting And Ranging), recently integrated on mobile devices such as the IPad Pro and the Apple iPhone 12 Pro, was tested in the architectural field. The digital scans, processed by the smartphone, were then compared with the output produced by the photogrammetric survey of the terrestrial type, processed on the same architectural object. On the basis of the results obtained, it was possible to evaluate the potential of these low-cost acquisition techniques in order to hypothesize new solutions and strategies for diagnostics and continuous monitoring, also functional for predictive analyses of the architectural heritage. The study was conducted on the Quadriportico of the Cathedral of San Matteo (east side), historical-architectural evidence of the Norman period in the city of Salerno (fig. I).

\section{Case study}

After several months of war, in December 1076, the Norman armies led by Roberto il Guiscardo conquered the city of Salerno, putting an end to the Lombard rule [Braca 2018, pp. 19-44]. With the conquest of the Opulenta Salernum, which enjoyed its greatest splendour in those years, the cathedral dedicated to the evangelist Matthew was built. The imposing building, financed by Guiscardo and designed by Bishop Alfano I, belonging to the Benedictine order, was built by exemplifying the model of the Abbey of Montecassino. It was visible from any point of the city being in the same place where the basilica of Santa Maria degli Angeli and the church of San Giovanni Battista were located, both demolished to make way for the majestic cathedral. The work began in I 08I, after a few months the Crypt was inaugurated which constituted the first nucleus in the construction of the Cathedral. Shortly after, the construction of the upper basilica followed, proceeding, as was the custom in medieval construction sites, from the transept to the quadriportico on whose southern side the monumental Norman bell tower was erected, built on commission from Archbishop Guglielmo da Ravenna [Memoli 2009, pp. | 83-185]. 
Fig. I.The Quadriportico of the Cathedral of San Matteo in Salerno. In the first picture above: east side also called 'side of nartece' From the left: south side west si north side.
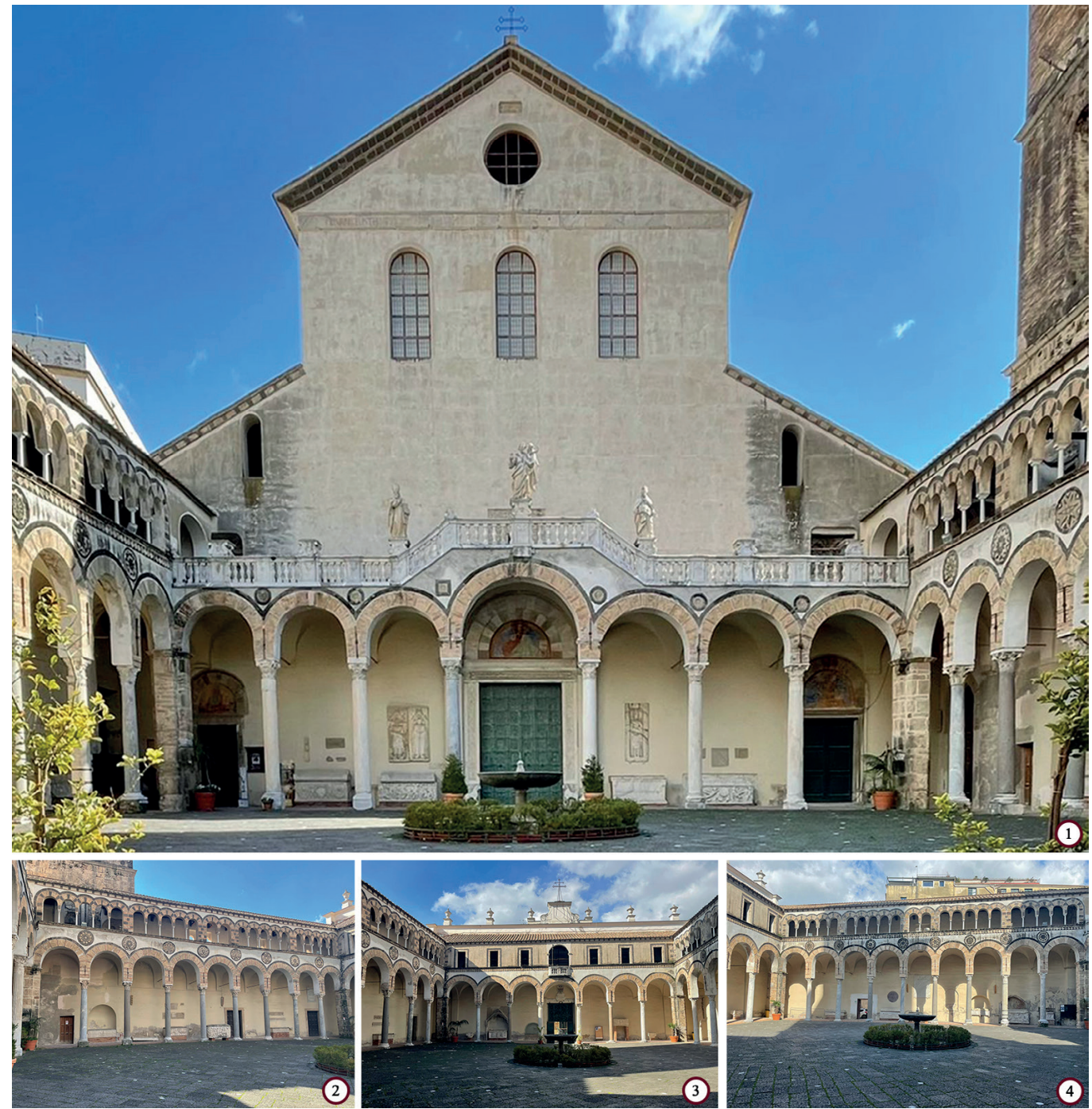

During the Baroque period all traces of the medieval Quadriporticus were completely lost. Only after the post-World War II restoration work, significant remains of the original layout of the atrium were found, completely hidden by plasters, plumes and cladding from the eighteenth century. Today, the atrium, better known as Quadriportico, consists of a portico supported by four corner pillars and twenty-eight columns [I], most of them coming from Paestum area. Along the portico there are several Roman sarcophagi [2] [Di Domenico 2020, pp. 135-145] while the facades of the arches, above columns, are decorated with ornamental inlays and rosettes which, together with the different stone materials, give a surprising scenic aspect. The loggia, on the other hand, positioned above the lateral arms, is characterized by two pairs of five-light windows arranged symmetrically on the sides of the central mullioned window. On the east side (side of nartace), stands the 'bronze door' of the Norman period, inscribed in a marble portal. It consists of 54 metal panels depicting, for the most part, Byzantine crosses. In the upper part, on the marble balustrade, there are the statues of Saints Matteo, Bonosio and Grammario [Braca 2003, pp. 5I-77]. 


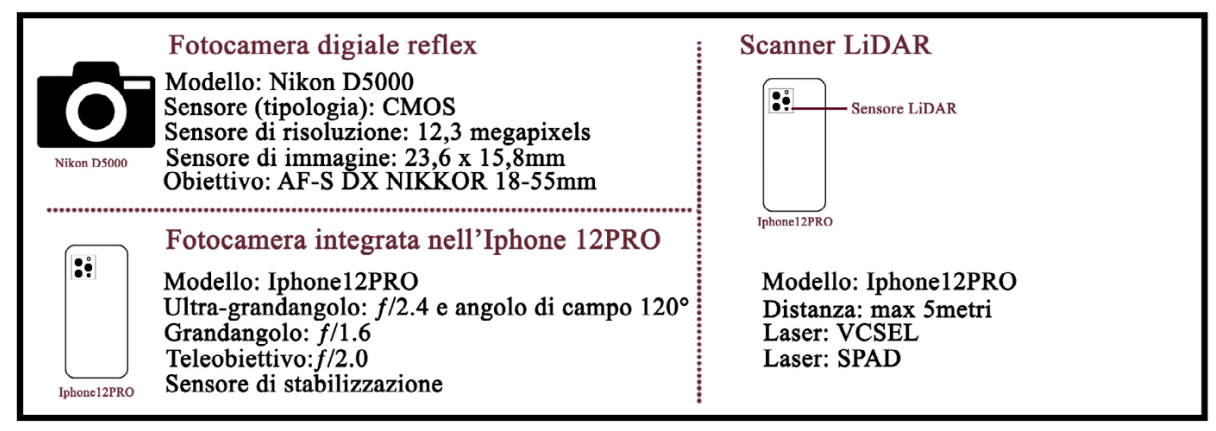

The low-cost sensors

Before proceeding with data acquisition phases, it was first of all necessary to evaluate both the technical and technological characteristics of the sensors used for the purposes of the research. Therefore, the survey conducted on the case study saw the use of two specific image-based and range-based methodologies with low-cost instruments: Nikon D5000 digital camera and an Iphone I2PRO smartphone (fig. 2). For the image-based technique, the dataset was recorded with a Nikon D5000 digital camera with CMOS sensor, with image size of $23.6 \times 15.8 \mathrm{~mm}$, resolution 12.3 megapixels and AF-S DX NIKKOR I8-55mm lens. To increase the stability of the images, a photographic tripod was also used during the shooting phase. Instead, for the range-based technique, as part of this research, we used the LiDAR sensor, implemented on smartphones. In fact, in the latest PRO version of the Apple model, this sensor has been integrated which consists of two main elements: a transmitter and a receiver, detecting maximum distances up to 5 meters in both outdoor and indoor environments. The sensor that transmits is a VCSEL (vertical cavity surface emitting lasers) array while the sensor that receives is of the SPAD (single photon avalanche diodes) type. By combining the information in real time, it is possible to read, via the app, the scan obtained discretized in the form of a triangular mesh. At the same time, important changes were also made to the rear photographic system [3] of the same smartphone, in particular to the quadrangular lens, equipped with a seven-element lens with $\mathrm{f} / \mathrm{I} .6$ aperture and to the ultra-wide-angle lens with aperture $\mathrm{f} / 2.4$.

\section{The photogrammetric acquisitions}

Initially, for the first phase of the survey, a terrestrial photogrammetric survey of the Quadriportico was carried out using a Nikon D5000 digital camera. The presence of the portico, however, required an important planning phase of the photographic campaign, in order to avoid blind spots and grey areas. Therefore, the dataset has been divided in relation to the elements: facade, porch and internal and external columns; in total, 602 frames were acquired, in which an overlap of the images of about $60 \%$ was guaranteed and, in relation to the conformation of the spaces, it was decided to set the focal length to $24 \mathrm{~mm}$ by integrating both parallel axis and with converging axes. In this way, spatial information on different depth levels was recovered while limiting distortion errors. For the survey of the columns [4], on the other hand, it was necessary to take 5 images along a semicircle for each column (fig. 3). Subsequently, the processing of the images was carried out with Agisoft - Metashape where medium quality parameters were set in all phases of the work (fig. 4). In line with the photogrammetric workflow, after the alignment phases the sparse cloud of 178,898 points was extracted. With the recognition of homologous points it was possible to obtain, with dense image matching algorithms, the textured polygonal model, consisting of a triangular mesh of 7,959,089 faces [Remondino 2017, pp. 59l-599]. Finally, the orthophoto used for the graphic processing of the side of the narthex was elaborated from the textured model (fig. 5). 
Fig. 3. Photogrammetric survey: workflow of data acquisition.
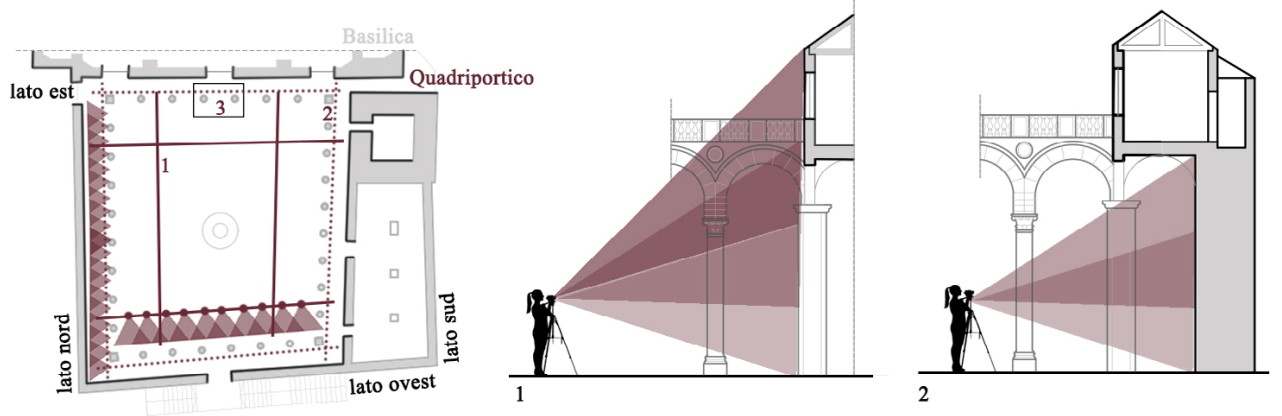

Rilievo fotogrammetrico del Quadriportico Schema della battuta fotografica

- 1_Facciate del Quadriportico

...... 2_Parti del sottoportico

- 3-Dettaglio colonna

Numero di fotogrammi acquisiti: 602

Tecnica di ripresa: Foto ad assi paralleli

Tempo di acquisizione: 1 giorno

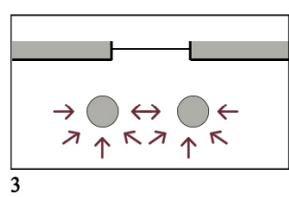

\section{Data acquisition from LiDAR scanners on mobile phone}

After evaluating the technological characteristics of the instrumentation examined, for the acquisition of data from smartphones, the survey was conducted exclusively on the east side of the quadriportico and then, for greater detail, on the architectural elements of the medieval door and the sarcophagus. by Guglielmo d'Altavilla, present on this side of the Quadriportico. In fact, during the Lidar scanner data recording phase, near the entrance door of the Church, there were several objects, which prevented the passage, creating

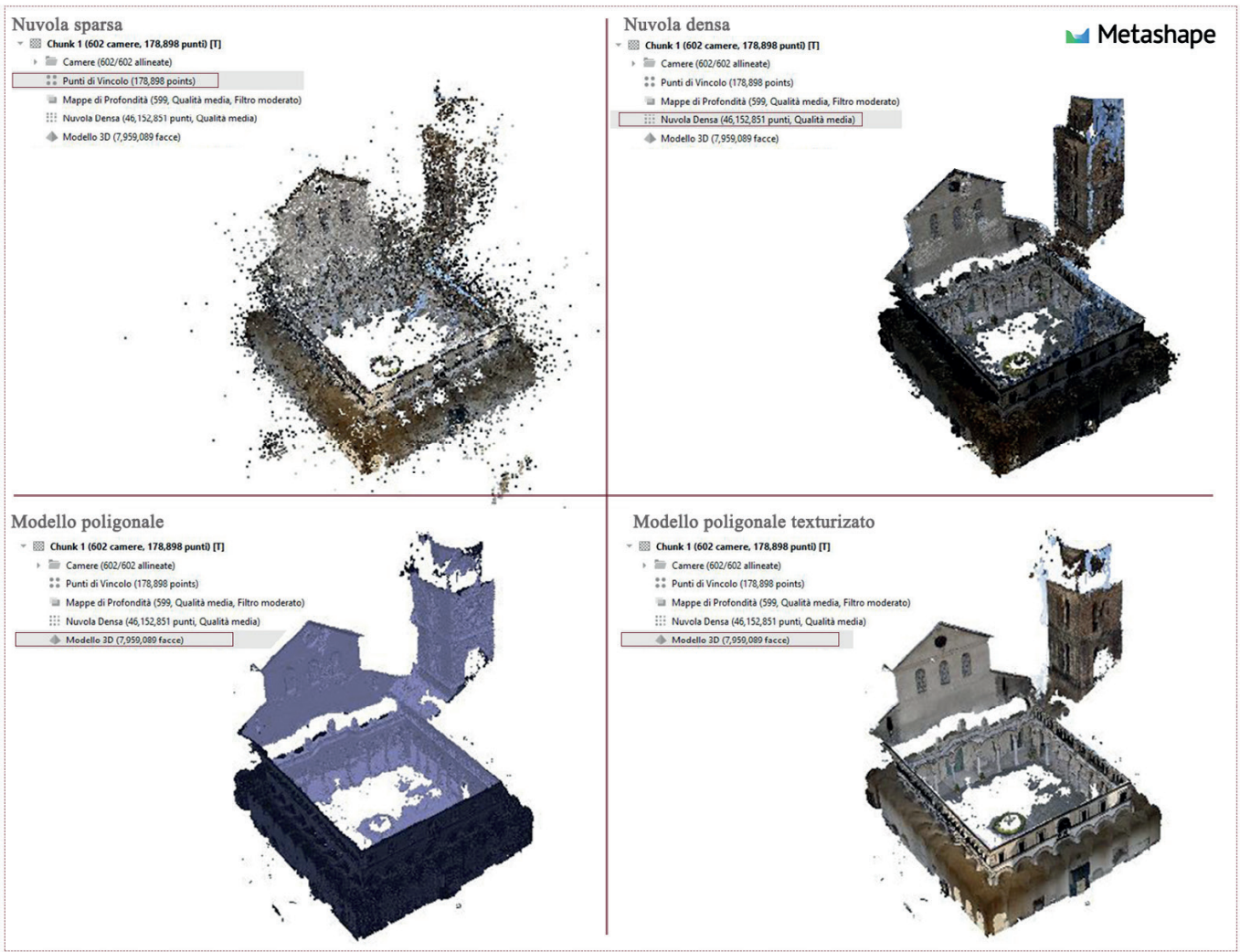




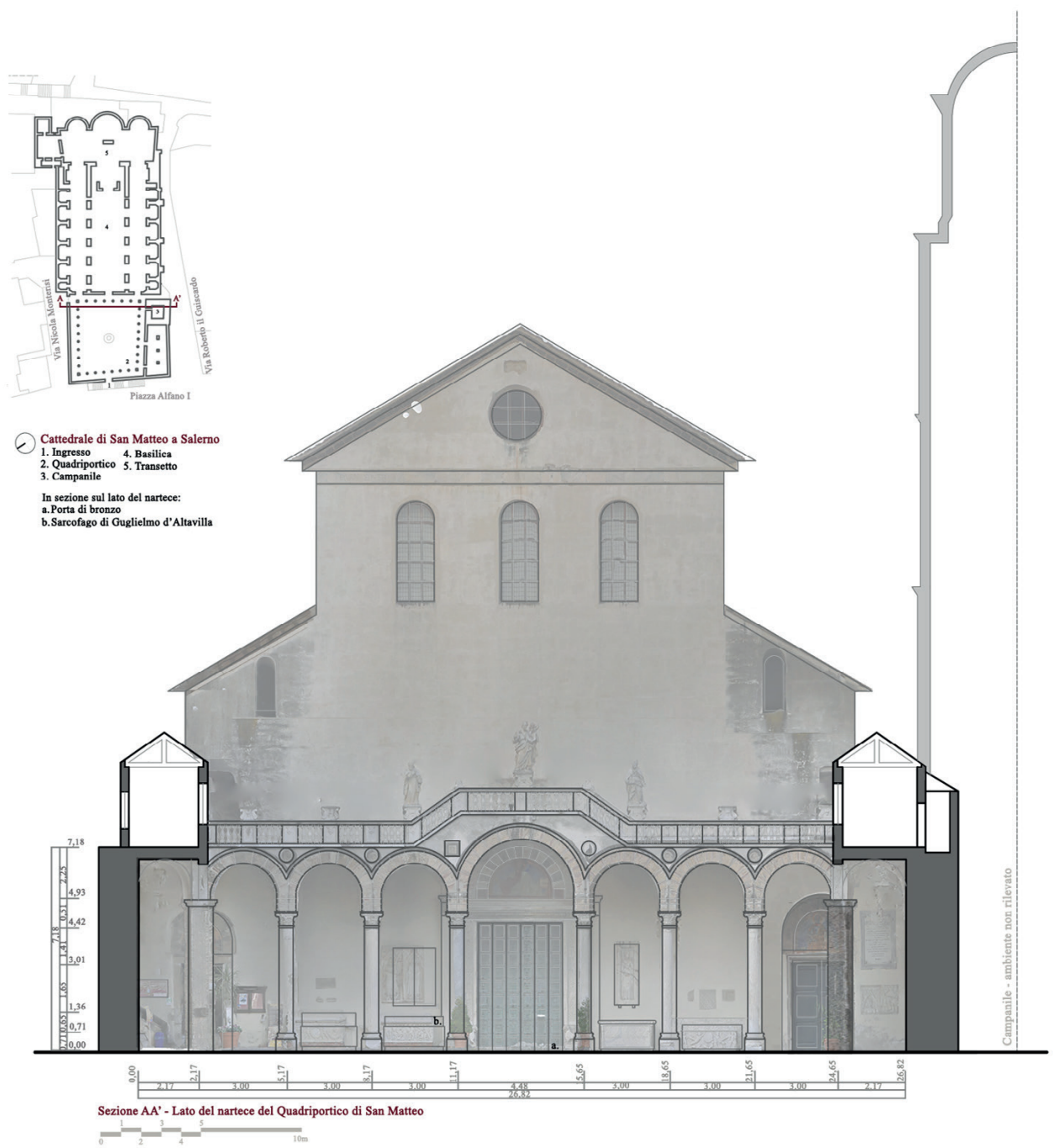

problems during the shooting phase. Therefore, for the purposes of comparison, this side has not been evaluated. The main objective was to identify the potential and limits of this sensor for which the various scans were recorded with both high res and low-res resolution parameters, setting the values from time to time through the app used, namely 3DScanner. Spatial information was collected by walking at a moderate pace and holding the smartphone in hand, with the sensor facing the architecture. Near the colonnade it was appropriate to rotate around each column trying to frame the parts of the base and the capital with more precision, while the vaulted ceiling of the portico was not detected by the sensor because it is 5 meters higher. To overcome this problem and acquire the upper parts, the smartphone was mounted on the telescopic bar. In 8 minutes the registration of the side of the narthex was completed. For the funeral monument and the medieval door, two more scans were made in about 6 minutes (fig. 6). Subsequently, again through the app, the textures were processed and, in this case, the parameters were again adjusted according to the size of the acquired object. It should be noted that this process took up 3GB of storage space and a processing time of about 22 minutes for scanning the entire environment, while the processing of the textures on the detailed parts took 5 minutes. These last two phases have considerably reduced the percentage of battery due to the high computational load. Finally, the scans were exported in the different formats available in the application (fig. 7). 
Fig. 6. LiDAR survey from smartphone: workflow of data acquisition.
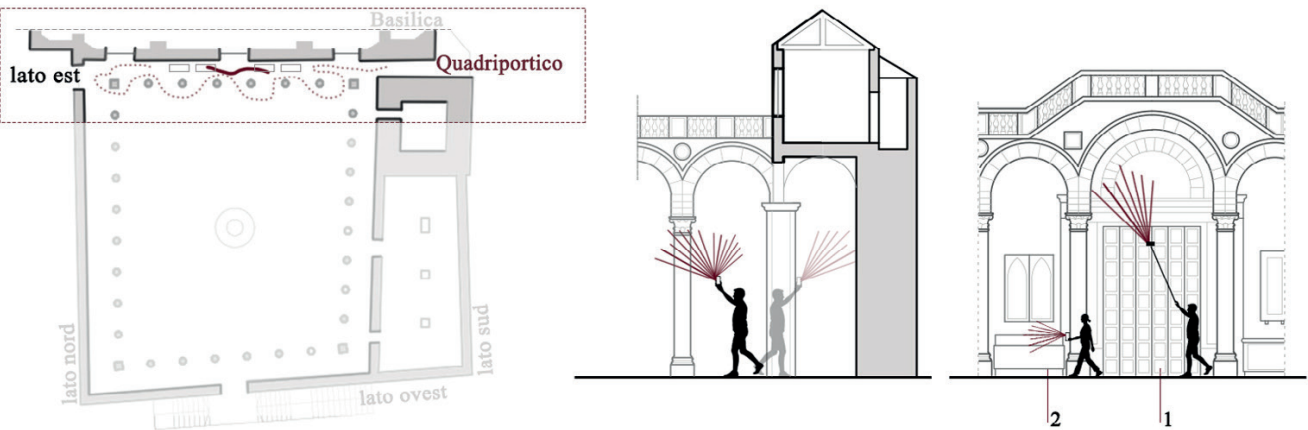

Rilievo LiDAR da Iphone12PRO

Schema della ripresa delle scansioni

...... Scansioni effettuate sul lato est detto del "lato del nartece"

- Scansioni effettuate sulla porta di bronzo (1) e sul sarcofago (2)

Tempo di acquisizione: 8 minuti per il lato est

6 minuti per la porta di bronzo e il sarcofago

\section{Comparison of data}

With the results obtained it was possible to make a first comparison between the two lowcost methodologies. In order to assess the accuracy of the two systems, it is also important to take into account the way in which the data were acquired. In fact, while for the first methodology a precise shooting technique was followed, for the mobile device the data were recorded in motion by moving freely from one side to the other. The first comparison saw the side of the narthex as the object of analysis, and the comparison of the points clouds took place within the software Cloud Compare, integrating the output of the photo-

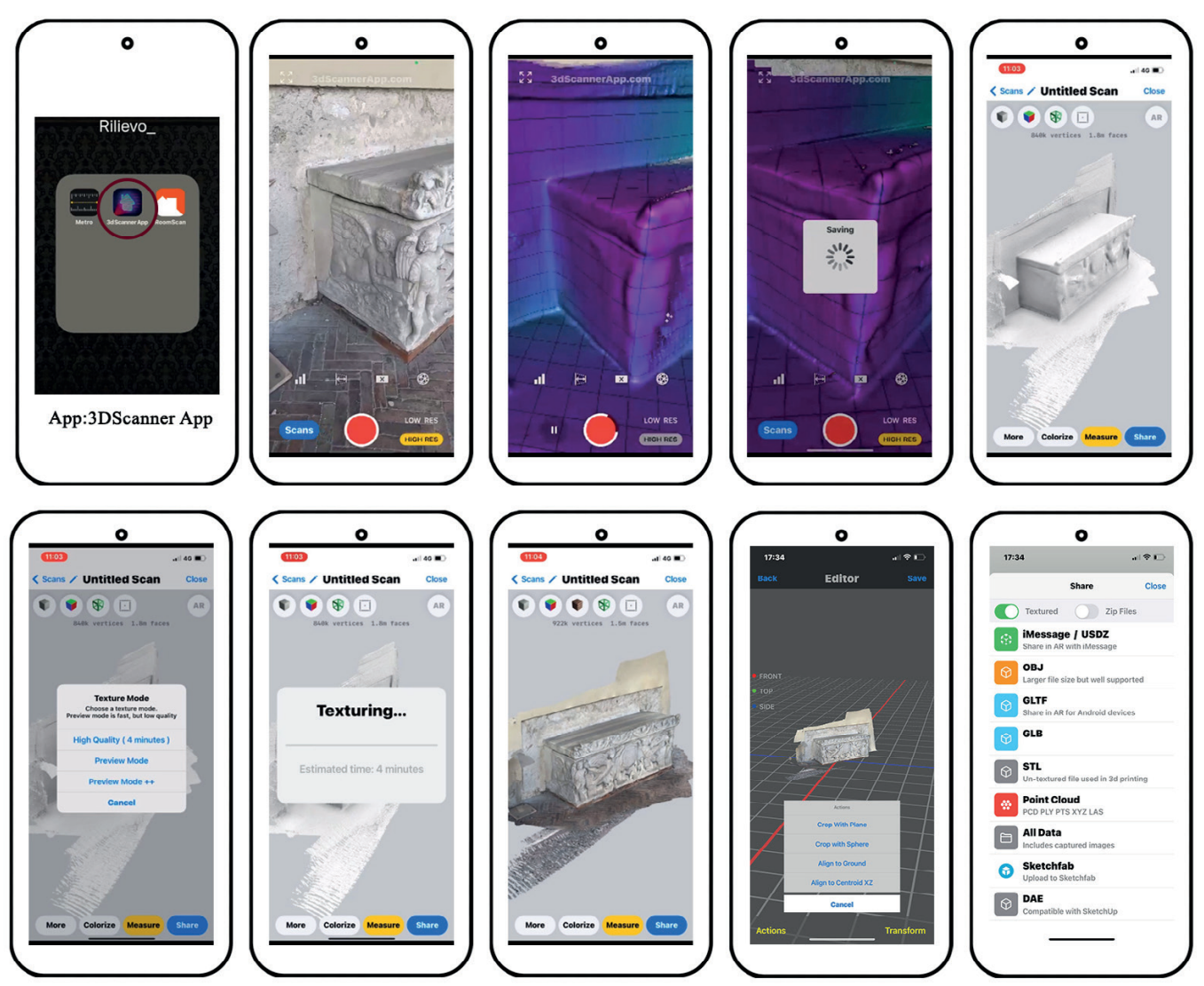

Fig. 7. Lidar survey from smartphone: data acquisition and data processing using the 3Dscanner app -
Sarcophagus of Guglielmo d'Altavilla. 
grammetric survey with the produced point cloud in a single model. from LiDAR scan. The photogrammetric dataset was chosen as a reference for the registration procedure with the ICP algorithm (Iterative Closest Point) and, starting from the collimation of the homologous points visible in each scan in the overlapping areas between two, they were calculated then the distance values. The result of the calculation cloud2cloud (C2C) showed, in the highlighted part under analysis, a large overlap area between the datasets with an average error of $0.16 \mathrm{~m}$ (Fig. 8). At the same time, with the same procedure, the detailed elements of both the bronze door and the sarcophagus were compared. In this case, the final alignment of the point clouds led to much more satisfactory results in terms of accuracy of the metric data with a maximum distance value contained within $2 \mathrm{~cm}$ despite the reduced acquisition phase times (fig. 9).
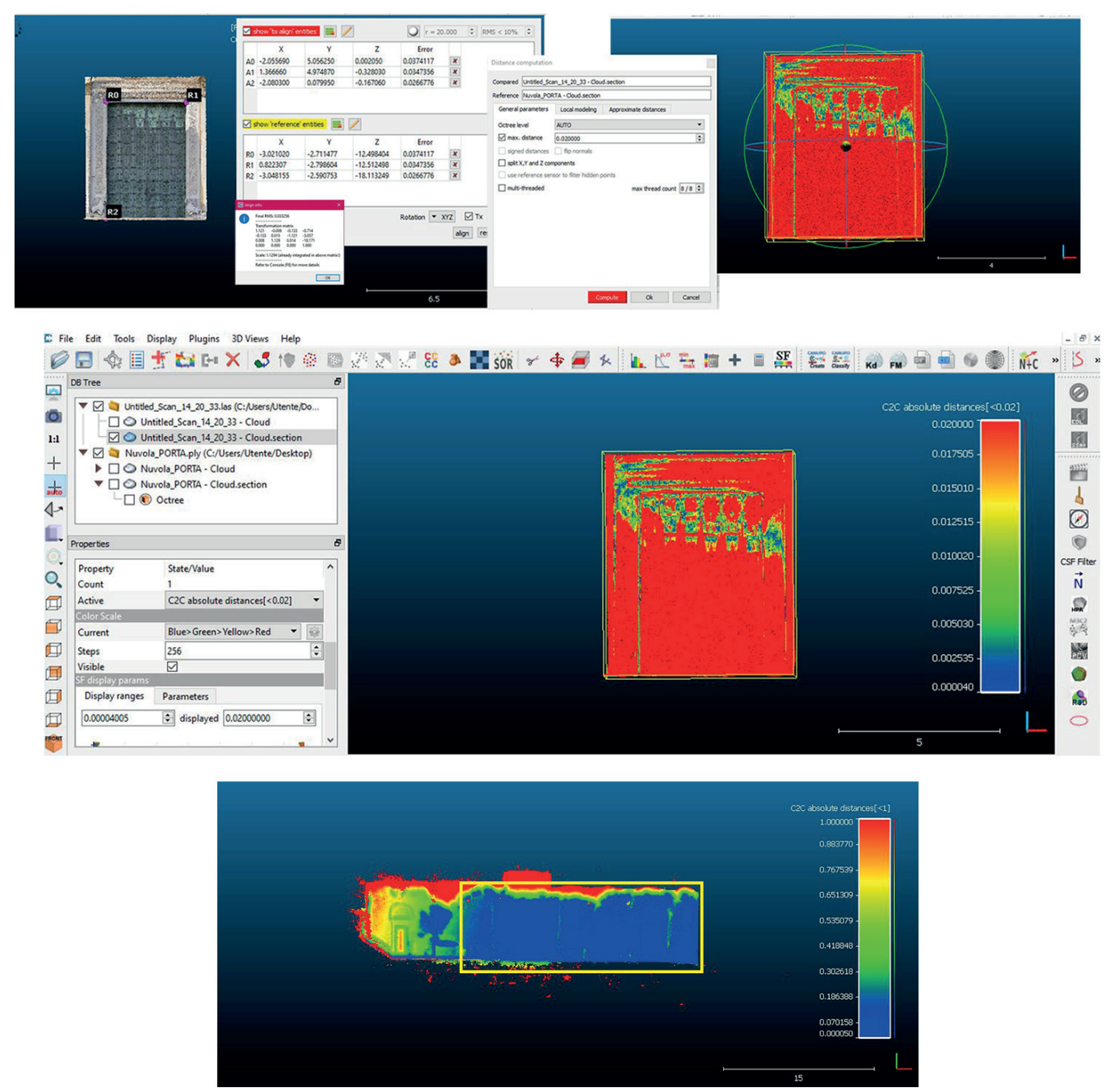

\section{Conclusions}

Considering that the LiDAR technology implemented on smartphones is mainly made for augmented reality applications and not yet for cognitive-architectural purposes, the results obtained from this first experimentation are satisfactory, especially considering the small size of the sensor and the portability of the device. Surely it is necessary to assess that the accuracy of the Lidar data is not yet optimal for large rooms as well as in the case of the narthex side, while it can be considered satisfactory for small objects. The techniques examined 
could be integrated with each other but, of course, the purpose of the survey to be carried out must always be kept in mind. For example, for the diagnostic and monitoring phases, where a continuous rapid mapping technique is required, the LiDAR methodology with sensors such as those used in this application can only serve as a support to consolidated techniques, such as digital photogrammetry. At the same time, however, we can assume that rapid further technological developments, regarding miniaturization and improved performance in terms of accuracy, will very soon allow new and interesting application scenarios with effective portable tools for surveying.

\section{Notes}

[I] Six columns are arranged on the two sides of the facade while eight are arranged along the other two sides.

[2] The Roman sarcophagi, inside the Quadriportico, are arranged randomly without following a precise chronological order.

[3] In this case, optical stabilization on sensor was adopted.

[4] Each frame was acquired by following a semicircle at $0^{\circ}, 45^{\circ}, 90^{\circ}, 135^{\circ}$ and $180^{\circ}$.

\section{References}

Barni R., Bianchini C., Inglese C. (2020). II duomo di Orvieto. Rilievo integrato e modellazione/The Cathedral of Orvieto. . In Arena A., Arena M., Brandolino R.G., Colistra D., Ginex G., Mediati D., Nucifora S., Raffa P. (a cura di). Connettere. Un disegno per annodare e tessere. Atti del $42^{\circ}$ Convegno Internazionale dei Docenti delle Discipline della Rappresentazione/Connecting. Drawing for weaving relationships. Proceedings of the 42th International Conference of Representation Disciplines Teachers, pp. 1678- 1699. Milano: FrancoAngeli.

Braca A. (2003). Il Duomo di Salerno. Architettura e culture artistiche del Medioevo e dell'età moderna. Salerno: Laveglia editore, pp. $51-77$.

Braca A. (20 18). Guida illustrata alla Cattedrale di San Matteo. Salerno: Opera edizioni.

Calantropio A. et al. (20 I8). Low-cost sensors for rapid mapping of cultural heritage: first tests using a COTS Steadicamera. In Appl Geomat, n. I0, pp. 3 | -45.

Di Domenico G., Galante M., Pontrandolfo A. (a cura di). (2020). Opulenta Salernum. Una città tra mito e storia. Roma: Gangemi Editore.

Di Luggo A. et al. (2019). Evaluation of historical heritage documentation: reality-based survey and derivative models. In International Archives of the Photogrammetry, Remote Sensing and Spatial Information Sciences, n. XLII-M I 7, pp. I I 5-I 22.

Memoli Apicella D. (2009). Sichelgaita tra longobardi e normanni. Salerno: Laveglia Carlone.

Remondino F. et al. (2017). A critical review of auto-mated photogrammetry processing of large dataset. In International Archives of the Photogrammetry, Remote Sensing and Spatial Information Sciences, n. XLII-2/W5, pp.59I-599.

Repola L. et al. (2019). La rappresentazione quale specchio del reale: le nuove tecnologie a servizio della conoscenza per la documentazione di ambienti complessi. In Belardi P. (a cura di). Riflessioni l'arte del disegnol il disegno dell'arte. Atti del $41^{\circ}$ Convegno internazionale dei docenti della Rappresentazione. Perugia, 19-2I settembre 20 19, pp. 96 I-968. Roma: Gangemi Editore.

Russo M., Giugliano A.M., Asciutti M. (2019). Mobile phone imaging for $\mathrm{CH}$ façade modelling. In International Archives of the Photogrammetry, Remote Sensing and Spatial Information Sciences, n. XLII-MV I7, pp. 287-294.

\section{Authors}

Marika Falcone, Università degli studi di Napoli “Federico II”, marika.falcone@unina.it Massimiliano Campi, Università degli studi di Napoli "Federico II", campi@unina.it

To cite this chapter. Falcone Marika, Cami Massimiliano (202I). II Quadriportico della Cattedrale di S. Matteo: sensori low cost per rilievi di rapid mapping/The Quadriportico of the Cathedral of S. Matteo: Low-cost Sensors for Rapid Mapping Surveys. In Arena A. Arena M. Mediati D. Raffa P. (a cura di) Connettere Un disegno per annodare e tessere Linguagoi Distanze Tecnologie Atti del $42^{\circ}$ Convegno Internazionale dei Docenti delle Discipline della Rappresentazione/Connecting. Drawing for weaving relationship. Languages Distances Technologies. Proceedings of the 42 th International Conference of Representation Disciplines Teachers. Milano: FrancoAngeli, pp. 2283-2300. 